\title{
Internal Marketing As A Strategic Tool For Survival In Nigerian Banking Industry
}

\author{
Pearse Olugbenga Ezekiel \\ Department of Marketing Lagos State Polytechnic Ikorodu
}

\begin{abstract}
Today banking industry is facing dramatic and aggressive competition in a new deregulated environment which was as a result of various banking reforms or policies that have been introduced by the successive Nigeria governments at one time or the other in the drives for economic sustainability and survival of the sector. The purpose of this study is to discuss how internal marketing could act as a strategic tool for survival in Nigeria banking industry. Relevant literatures were reviewed to ascertain the potential internal marketing has and as the paper also argues logically the relationship between internal marketing, quality service delivery, customer satisfaction and loyalty with the goal on organizational survival and profitability. The study recommended that necessary laws and regulations bothered on the banking employees performance and operations should be formulated and ensuring compliance, while concerted effort should be made in discouraging banking institutions from deploying anti-welfare policies and strategies that are imminical to their workforce. Banking reform should be carefully implemented to ensure that banks are better positioned to perform their strategic roles and duties to customers, employees, investors and the society at large.
\end{abstract}

Keywords:- Internal marketing, banking industry, economic sustainability, quality service delivery, customer satisfaction and loyalty, banking reforms, aggressive competition

\section{INTRODUCTION}

Organizations in Nigeria's service-oriented industry today operate in a complex, dynamic and ambiguous environment which are characterized with the continuous changes that consistently take place in its socio-cultural, economical, political, technological and international situations. This sector is faced with severe competition in the global financial markets. The need to survive and the desire to sustain their existence make organizations to be more conscious of their relationship with their present and potential customers. Banking being one of the largest industries in Nigeria have recently assumed more prominent roles in the economic growth and development of the nation. The service oriented industries globally are currently undergoing a radical transformation owing to the growing effects of liberalization, privatization and globalization measures or policies introduced by the economies of the world towards the end of the last century and most especially in the areas of telecommunication, tourism, hospitality, insurance, banking ,educational, transportation, healthcare as well as entertainment. This trend has equally lead to stiff and intensive competitions among major businesses in the world over. In most developing countries like Nigeria, about $60 \%$ of the workforce are employed in these service oriented sector that include retailing and wholesaling, tourism and hospitality industries, educational institutions, medical and hospital services, recreation and entertainment industries, financial services as well as communication and construction industries to mention just few (McColl; Callaghan \& Palmer, 1998). By early 2000 , it was estimated that by 2010 service oriented industries will be accounting for about $52 \%$ of the GDP of the developing nations of the world which can thus help to raise the national income, the level of employment, the balance of payment and foreign exchange rates(Hill, 2007;Petzer \& Steyn ,2008). Though, Nigeria business climate of huge unmet demand offers little incentives for top management to engage in employee or customer's oriented strategies that will ensure continued success of their businesses. Organizations because of these environmental dynamism and increases in competition imbibe them to be more sensitive to customer altitude and satisfaction (Aghazadeh, Estiri \& Osanlou, 2007). These high level competition, expectations and changing technological and business prepositions make the banking industries to think more of the appropriate marketing approaches that can deliver satisfactions to customers because operating successfully in this environment require one having the right type of personnel in the right atmosphere and mind to survive and create a sustainable 
competitive advantages through quality services that will ultimately aid the survival of these organizations. Parasuraman, Zeithami \& Berry $(1985 ; 1990)$, also posited that the key strategy for the success and survival of any business institution is the deliverance of quality services to customers. Ravichandran, Prabhakaran \& Kumar (2010), opined that the level of service quality offered will determine customer satisfaction and attitudinal loyalty. Customer satisfaction is one of the important outcomes that serve to link processes culminating purchases and consumption with post purchase phenomena such as repeat purchase, brand loyalty and altitude change. In order to sustain the impetus of customer loyalty and company survival, banking organizations continually seek to acquire, retain and increase business bearing in mind the cost of losing customers. Studies have also suggested that failing to deliver a high-quality customer experience can result in a staggering erosion of a company customer base because customers are evolving; the traditional shopper has been joined by the digitally oriented, multichannel customer, social media sites and online research are also accelerating personal selling activities (Robinson \& Brown, 2012). According to conventional wisdom, a dissatisfied customer might tell 10 people of a negative experience; today social media enables that same customer to reach thousands with a few keystroke. Therefore, necessary steps are to be taken by organizations to address these challenges that might possibly derail the futuristic projections of management of banking industries and any model or approaches to be adopted must accommodate and address all these challenges. Achieving these utmost tasks and objectives now depend primarily on organization's desire to deliver quality services and experience to meet with ultimate expectation of the target customers. Whereas, the quality of services rendered by company also depends on some major factors which significantly contribute to the sustenance of organization reputation and customers faithfulness, the antidote to these challenges are the adoption and understanding of the concept "internal marketing" which is seen as major activities in the development of a customer - oriented organization (Seyed Javadein, Rayej, Estiri \& Ghorbani, 2011). The term 'internal marketing' as postulated emphasizes on viewing employee as partner to organization's effort at achieving organization success rather than cost, therefore seeing them as the organization most valuable asset and treating them as internal customers based on the notion that employee represents an internal market within an organization or segment which needs to be informed, educated, developed and motivated so as to be able to achieve the organizational objectives by delivering quality services that can meet up with the desire of the customers. Berry (1981), sees the concept "internal marketing" as seeing employees as customers just like external customers, internal customers need to have their needs satisfied. The satisfied employees are the biggest asset to an organization whereas the greatest liability is the dissatisfied employees. Gummesson (1991), also stated that internal marketing is an essential component of marketing oriented organization. while Morgan (1991), also posited that a marketing-oriented organization will adopt internal marketing readily by identifying its potentials in gaining a long-lasting employee into an integral part of the product offering and since service production and consumption are simultaneous, the direct human contact in between the service provider and the customer cannot be overemphasized (Mudie, 1991 \& Coller, 1983). Effective marketing of this segment goes a long way in contributing significantly toward the success of external market. A number of studies have been undertaken globally to emphasis the relationship or otherwise between internal marketing, customer satisfaction and organization survival most especially in the banking industry. While substantial numbers of them strongly supported and agreed that internal marketing is a veritable tool in service delivery that ultimately enhances survival in the banking industry due to the nature of the products offered while fewer numbers of them believe otherwise (George 1977, Berry 1980, 1981,1983, Band 1988 \& Harari 1991,1993, Guaspari 1991, Barnes 2000). In this regard, it is not quite certain if truly internal marketing concept can help as synergy or serve as surviving tool for banking industries. Therefore, the main objective of this paper is to argue the extent internal marketing can go in delivering quality services that might lead to conative and action loyalty with a fundamental impact on the organization survival and also sees the relationship between internal marketing and survival of banking businesses and how they could act as a formidable tool for survival in Nigeria service oriented industries and beyond. In doing this, the paper will attempt to fill the knowledge gap and contribute immensely to both public and private establishments in developing economies and beyond. The policy-makers will also find it useful in the area of policy formulation and strategic implementation. This paper is organized into 4 sections. Section one introduces the topic of the research. Section two reviews the related literatures on internal marketing and survival of banking industry. Section three ex-rayed the nexus between internal marketing and customer satisfaction. While section four discusses the conclusions and recommendations. 


\section{REVIEW OF LITERATURE}

\subsection{INTERNAL MARKETTING (IM)}

Organizations that select, develop, manage and motivate their workforce in order to produce outstanding business results have an extraordinary competitive advantages compare to others. The term internal marketing originates from the service marketing literature with focus on developing customer-conscious employees with the aim of turning service quality into an organization imperative. The genesis of internal marketing (IM) can be traced to the early works of Berry, Hensel \& Burke (1976), as well as Sudhir \& Sangitta (2010), who viewed internal marketing as a strategy whereby an organization designs its jobs and markets itself to its employees as though the employees were the firm's (internal) customers. The use of marketing in the context of internal marketing (IM) suggests that Internal marketing as a concept evolved from the simple idea that employees constitute an internal market within the organization, which need to be recognized, informed, trained and re-trained, motivated and rewarded in meeting the needs of the external customers and expectations(Varey \& Lewis, 2000). Various authors at one time or the other have defined internal marketing and viewed it from different perspectives among which is Berry $(1981$,$) that opined that the concept of internal$ marketing is all about viewing "employees as internal customers" whose needs must be satisfied just like the external customers. Reasons why George (1977), emphasized that for obtaining external customer satisfaction, service firms should first concentrate on their internal customer i.e employee satisfaction. Berry \& Parasuraman (1991,p. 151), strongly argued internal marketing as the strategy of attracting, developing, motivating and retaining qualified employees through job-products that satisfy their needs, i.e internal marketing is a philosophy of treating employees as customers. Che Ha, Abu Bakar \& Jaffar (2007), viewed internal marketing as an important concept where firms apply marketing tools to attract and retain the best employees which ultimately enhance the business performance because of the believe that the satisfied employees are the biggest assets to an organization whereas the biggest liability is dissatisfied employees.

Mudie (1987), also supported this argument based on the tendency of internal marketing in turning the front-line employees into an integral part of the product offering since service production and consumption are simultaneous in service industries. Cottier (1983), opined that the direct human contact between the service providers and customers is irresistible, hence employee relation becomes more vital in providing good and quality services. Internal marketing helps so that organizations are able to market successfully the idea of service quality becoming the organization mission from the management to the manager, from the manager to the staff and from the staff to the customers. Nattala \& Kameswari (2009), viewed that service oriented organizations with desire to excel need to attract and retain customers to ensure a sustainable competitive advantages as the employee plays major roles in attracting, building and maintaining relationships with customers with emphasis that delivering quality service is the fundamental tool for customers' satisfaction (Powell, 1995). Ruyter \& Bloemer (1995), see quality services itself as an antecedent of customer satisfaction and they further emphasis that the major key of retaining customers is to increase the service quality level whereas, people element is the most important aspect in delivering quality services especially where the product is standardized like in the banking industries. Front-line employees are responsible for ultimately delivering the service (products) to external customers. In services, the production and consumption take place on the service encounter as exemplified in this diagram 

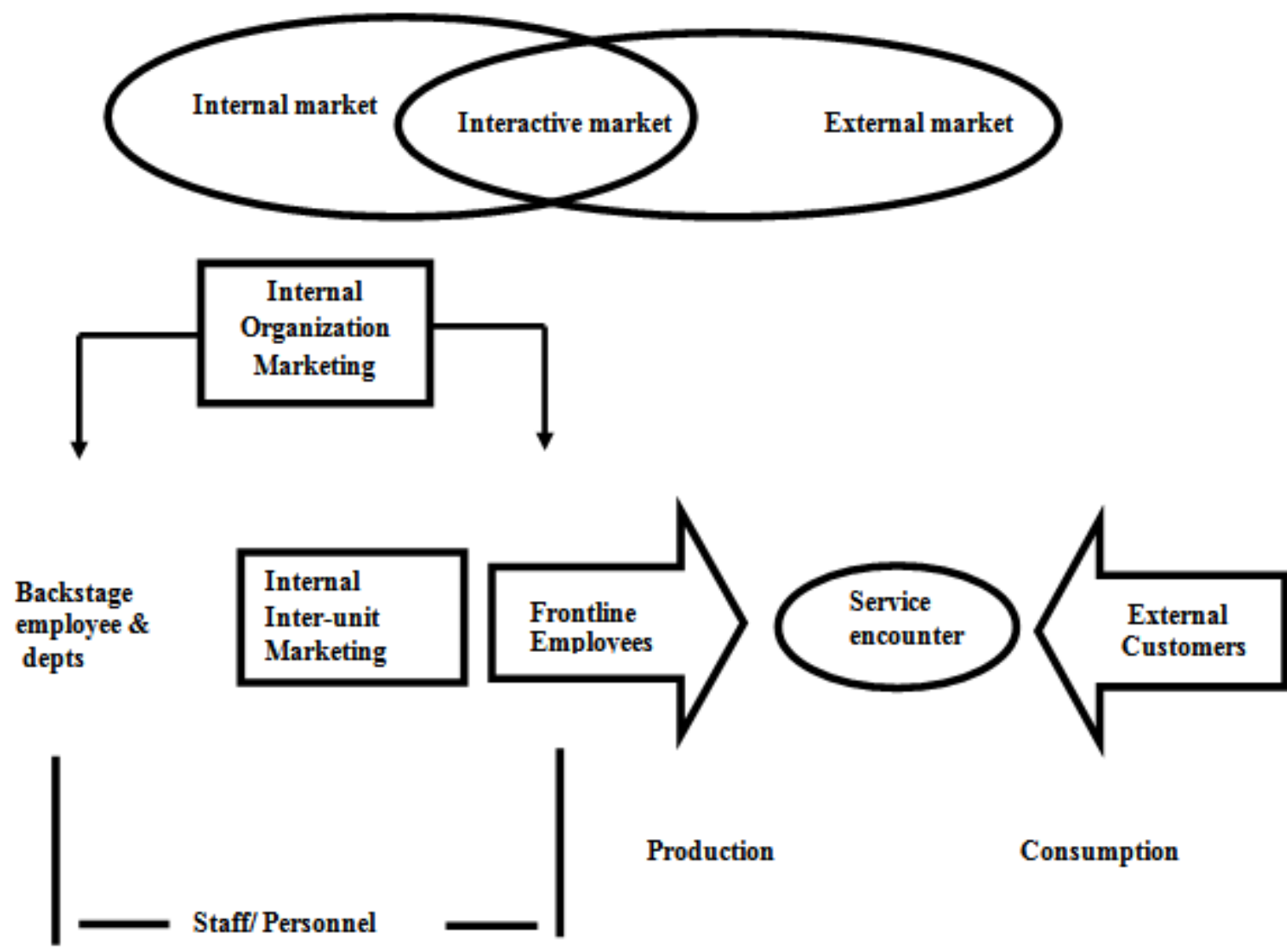

Internal Marketing Interaction Sources Joseph (1996, P.56)

IM is viewing employees as internal customers, jobs as internal products, and endeavoring to design these products to meet the needs of those customers better i.e applying the philosophy and practices of marketing to the people who serve the external customers so that the best possible people can be employed and retained and they will do best work possible (Salomao, 2010).

Based on these arguments, various authors have reviewed necessary literatures on the elements, components and common steps in internal marketing so as to give better understanding of the concepts and see how beneficial it could be in sustaining banking activities in this highly complex and competitive business environment like Nigeria. They began to recognize that IM can help company in achieving its strategy. Most especially if strategies are to be implemented more effectively, internal conflicts must be overcome and internal communication improved. Today IM is seen as "a way of reducing departmental isolation, reducing internal friction and overcoming resistance to change" which can be applied to any type of organization. Reynoso \& Mooress (1996), have identified six common steps in internal marketing campaign which if adequately adopted can enhance the internal customers (employees) performance in delivery quality services that can meet the needs and desires of the external customers adequately. The major steps of interest begin with the creation of internal awareness within the employees in the organizations; adequate communication is a monumental motivational tool in achieving an effective internal marketing campaign (Piercy \& Morgan, 1990, 1991 and 1995). Organization internal awareness is seen as a spontaneous sensing of an organization employees on what arise with them based on what they are doing, their feelings and their future plans that are mostly characterized by contact, by sensing, by excitement and by gestalt formation (Perls,Ralph \& Goodman, 1951). This is followed by identification of internal customers and internal suppliers which is seen as a major effort in internal marketing campaign because the interactions between internal suppliers and customers must be identified and the communication associated with this interaction should be properly examined to see the possibilities for improvement. The step three entails the identification of the expectations of the internal customer which encompasses the desires and aspirations of the organization employees as well as all categories of needs as 
expressed by the internal customers in meeting their expectations appropriately. The communication of these expectations to the internal suppliers (organizations management) in order to discuss their own capabilities and / or obstacles in meeting these requirements is also essential in achieving an effective internal marketing campaign. Based on the previous points and understanding, the internal suppliers should then make appropriate changes required so as to be able to deliver on the level of services and programmes also expected. Finally, there should be mechanism for measurement and feedback if services are programmed to be improved upon. Bansal (2001), also describes the elements of IM to also include, employment security which provides assurance that they will not be laid off even during high economic cycle, extensive training as a mean for requisite knowledge and ability to recognize and solve problems, providing higher-than-industry-average salary which show the way of communicating the value of employees to the organization.

Ahmed \& Rafiq (2000, 2003, 2004), also argued that an effective internal marketing campaign can be achieved if organization understands in detail the basic elements of internal marketing and determined to work collectively in achieving these, the elements identified includes;

a. Employee motivation and satisfaction;

b. Customer orientation and satisfaction;

c. Inter-function coordination and integration;

d. Marketing-like approach to the above listed issues;

e. Implementation of specific corporate and functional strategies.

The authors further introduced in their expressions the major component in 'internal marketing mix' as price and payment, sales promotion (education, empowerment and communication), working environment or place as well as process (job products), this opinion were also supported by Galpin (1997), as predicated on his study in Malaysia about internal marketing. See also Piercy \& Morgan (1991), Drake (2005)\& Nalbantian (2004). With regards to the thought of various authority concerning internal marketing concept and it implications on the survival of Nigeria banking industry, we observed the key concepts of internal marketing to include;

- Internal marketing (IM) functioning as a continual internal 'up skilling' process

- $\quad$ Alignment of the organization's purpose with employee behavior

- Motivation, reframing and empowerment of employee attitude.

- $\quad$ Inside-out management approach.

- $\quad$ Retaining a positive customer experience throughout the business objectives.

The major essentials of successful internal marketing i.e the most important areas within the organization's internal environment which are essential for an internal marketing programme are;

$\begin{array}{ll}\text { - } & \text { Motivation } \\ \text { - } & \text { Co-ordination } \\ \text { - } & \text { Information } \\ \text { - } & \text { Education. }\end{array}$

Consequent on the nature of business of major service - oriented organizations such as entertainment, tourism, telecommunication, hospitality, insurance, banking, education, transportation, healthcare and for the fact that service production and service consumption are simultaneous in banking industry. Also with the fact that businesses have realized that they have to move with the times, particularly in terms of technology, market strength, sales potentials, internal capability and organization images and even the fact that an organization employees are one of the most important resources that provide differentiation in banking industry and the growing emphasis on competing through superior service quality relies ultimately on the behavior and effectiveness of the people who deliver the service rather than people who design the strategies and the believes that the success of any strategy lies on the ability to gain the effective and enduring implementation of the strategies rather than the ability to conceive and design the strategies. The argument further stresses the potentials of internal marketing as a key in;

Commitment to the goal of guaranteeing the best possible treatment of customers.

Participating actively in achieving organization's goal.

Creating a potential for long-term success 


\subsection{INTERNAL MARKETING \& BANKING INDUSTRY}

The banking industry of any nation in the world plays more significant roles in economic growth and development of the country, in fact, how healthy the banking system of the nation is will determine the wellbeing of the economy of that nation (Osaze, 2000). Nigerian banking system desire for economy sustainability growth and the need for a stronger, robust and sounder banking activities and program, globalization of operations, public acceptability and desired sales coverage, technological innovations and the adoption of supervisory and prudential requirement that are in line with international standards and requirements have pull and push them through various policies starting from the era of free-banking to era of consolidation growth, indigenization and deregulation era up to the present era of bank consolidation and to support what Ritzer in 2003 refer to as McDonaldization which connotes increasing rationalization of everything in order to achieve maximum results (Nwankwo,1990). Today banking industries are facing dramatically aggressive competition in a new deregulated environment with the presence of more investors in the business arena from both national and international sphere injecting billions of dollars in direct investment, share acquisition, management transfer as well as merger and acquisition. Banking customers are expecting better choice in operation with enhanced human and materials facilities to facilitate service delivery and build strong loyalty with a deep commitment to re-buy or re-patronize a preferred product/services consistently in the future time. Research has also proved that customer loyalty is an important element of banking success in today's increasingly competitive environment (Mukhiddin, Dileep \& Jalal 2012). Therefore, any desired banking institutions must develop appropriate strategies that can coordinate all the internal variables that will result in delivering quality service to the target audience in meeting their diverse needs with the believe of improving customer loyalty and trust through empathetic attitude. The tendency of offering quality services to customer depends on the individual who is rendering the services justifies why human element can never be over-emphasized in banking services. And since in the process of banking service delivery, a firm's frontline employees actively interact with the customers, and in effect, become the public face of the service establishment. The nature of this interaction plays a huge part in the overall quality service experience as perceived by the customer. Various studies in the internal marketing area have shown that these variables; employees commitment, quality services and customers loyalty seen to be crucial in influencing one another (Mukhiddin, Dileep \& Jalal, 2012, Hossein, Sima \& Ebrahim 2012, Lings \& Roger 1998, Kameswari \& Nittala 2012, Papasolomou- Doukakis 2002, Javadein, Rayej, Estiri \& Ghorbani 2011, Robinson \& Brown 2012, Petzer, Steyn \& Mostert 2008, Wieseke, Ahearne, Lam \& Van Dick, 2009 ).

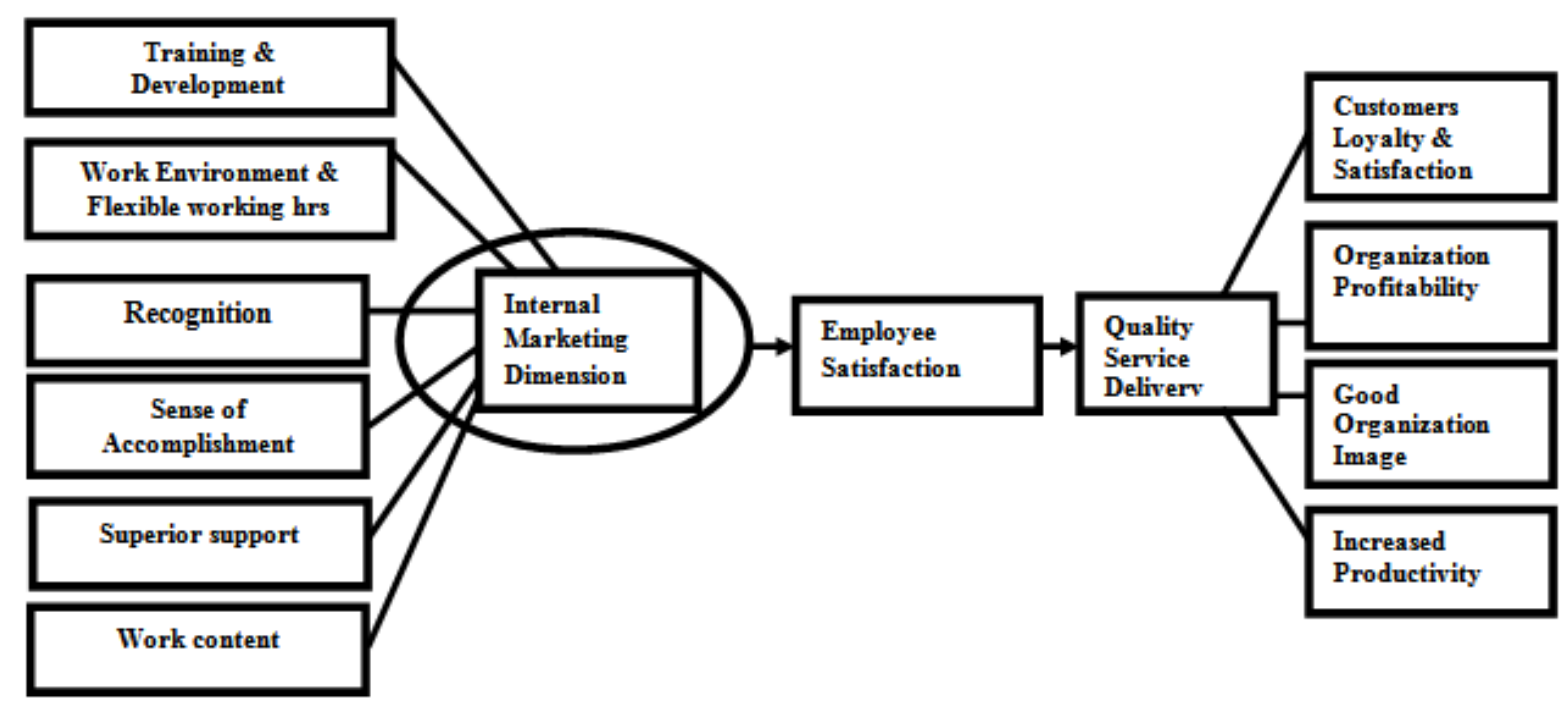

Figure 2: The modified research model for the internal marketing dimension of employee satisfaction and quality services delivery.

Research in service marketing have also suggested that deficiencies in internal marketing (IM) add to cost of doing business and lower employees as well as customers satisfaction. Consequently, Sasser \& Arbeit (1976), also concluded that by augmenting internal products offerings with such things as flexible working 
hours, salaries and other benefits, company can facilitate internal exchange. Miles, Hatfield \& Huseman (1991), also emphasized that those less tangible social benefits are also important in the external exchange and these includes: status, recognition for good work and sense of accomplishment because in an organization, employee is the individual that runs the job that provides a service to internal and external customers. Today banking industries should understand that focusing on marketing strategies alone is no longer sufficient to sustain a company survival in a tough market situation like Nigeria. The era when most service-oriented organizations see or perceive their employees as a depreciating assets should no longer be encouraged because investment in employee development does not have depreciation values thus it should be perceived as capital and one of the company vibrant assets that must be strengthened and developed for ultimate delivery of the desired results as expected. Any service-centered organization that practices an effective internal marketing concept stands the benefits of deriving adequate results from the contented employees that IM creates. Various authors have also indicated strong positive relationship between employees' satisfactions and customers' satisfaction (internal and external). They all opined that satisfied employee is highly motivated to deliver results and serve customers better which will directly create satisfied customers and indirectly building and increasing customers' loyalty and better profit for the organization. Internal marketing also builds and create internal relationship between people of all levels in an organization through the development of service and customers oriented mindset of individual employees (Kelemen \& Papasolomou-Doukakis 2004, Hossein, Sima \& Ebrahim 2012 ,Sudhir \& Sangita 2011, Papasolomou-Doukakis 2002, Ian \& Roger 1998, George 1990, Walter, Gary \& Larry, 1994).

\section{CONCLUSIONS}

The study examined the nature and activities of the major banking industries in developing economies like Nigeria and the roles internal marketing could play in solving the problems peculiar with most serviceoriented establishments. The study acknowledged the relevance of internal marketing as a strategic tool for successful external marketing. Recent developments in the banking industry have justified the critical roles of employees in achieving superior service quality and customer satisfaction which ultimately result in customer retention. Nigeria banking industry should encourage and practice internal marketing which has the potential to influence the attitudes and behavior of staff towards service and customer orientation. The literatures reviewed also revealed that the internal marketing dimensions have a significant impact on the satisfaction level of major banks employees which actually translate to better productivity in quality service delivery, employee contentment and job fulfillment, sense of accomplishment that motivate the employee to go extra miles in meeting their customers' needs and desires with less time (empathetic attitude). Today banking industries should see their employees as internal product offering that must be adequately augmented with such things as flexible working hours, good and commensurate salaries and other benefits, sense of recognitions, job security even during the period of recession adequate training and development, timely information dissemination and promotion at due time, all these make the employees to have a customer-oriented mindset which will lead them to treat external and internal customers equally. Banks management should also dissociate from some counterproductive policies and strategies such as out-sourcing of some banking operations, casualisation of workforce or contract staffing, McDonaldization e.t.c which they hope might reduce the cost of doing business but in the long run increases labour turnover, cost of training and cost of integrating new employees and also resulting in confusion, misunderstanding and frustration among staff of major banking institutions.

\section{RECOMMENDATIONS}

For banking industry in Nigeria to make lasting impact as a stakeholder in socio-economic development in the country and beyond, the following policy prescriptions and recommendations are put forward. Firstly, Nigerian banking regulatory agencies such as CBN, CIBN and other bodies should make concerted effort towards making sure that necessary laws and regulations concerning employees' welfare and operations are formulated and steps are taken in ensuring compliance within the banking sector i.e treating employees' as customers. Secondly, steps should be taken in persuading banking industry from deploying antiwelfares' policies and strategies such as casualization of workers, contract employment, outsourcing, unfriendly conditions of service and conditional employment so as to be able to restore the employees' confidence in his/her activities which will translate to better and quality service delivery that will result in customers' loyalty. 
Furthermore, the current banking reform by the CBN should be carefully implemented to ensure that banks are better positioned to perform their strategic roles and duties to their customers ,employees, investors and the society at large.

\section{REFERENCES}

[1]. Aghazadeh, H., M. Estiri \& B. Osanlou (2007) Competitiveness of Iranian enterprise.

[2]. Barnes, J.G. \& Rowe, G. (1998) Relationship marketing and sustained competitive advantage. Journal of Market focused Management 2, 281-297.

[3]. Berry L.L., Zeithaml V.A \& Parasuraman A. (1990) Five imperatives for improving service quality, Sloan Management Review.

[4]. Berry, L. L. (1981), 'The Employee as Customer', Journal of Retail Banking, Vol.3, March, pp.2580.

[5]. Berry, L.L. \& Parasuraman, A. (1991) ' Marketing Service'’. New York: The Free Press.

[6]. Che Ha, Abu Bakar \& Jaafar (2007) 'Internal Marketing Issues in Service Organization in Malaysia', International Review of Business Research Paper, Vol 3 No. 5Pp 134-145.

[7]. Collier, D. (1983) Managing a service firm: a different management game. National Productivity Review Winter, 36-45.

[8]. Emeka W. Dumbili (2013) McDonaldization of Nigerian Banking Industry in the post-consolidated era; An exploration of the Unavoidable consequences. Mediterranean Journal of Social Sciences.

[9]. George, W.R. (1990) Internal marketing and organizational behavior: a partnership in development customer-conscious employees at every level. Journal of Business Research 20 (1), 63-70.

[10]. Gronroos, C. (1990) Service Management and Marketing: Managing the moment of truth in service competition. Oxford Maxwell Macmillian.

[11]. Gummesson, E. (1991) Marketing-orientation revisited: the crucial role of the part-time marketer. European Journal of Marketing 25(2), 60-75.

[12]. Levitt, T. (1960) Marketing myopia. Harvard Business Review July-August, 45-56.

[13]. Lings, I.N. \& Brooks, R.F.(1998) “ Implementing and measuring the effectiveness of internal marketing”, journal of marketing management, vol. 14,pp.325-350.

[14]. Morgan, N.A \& Piercy, N. (1990) Marketing in financial services organizations: policy and practice. In R. Teare, Moutinho and N. Morgan (eds) Managing and Marketing Services in the 90s. London: Cassel.

[15]. Mudie, M. (1987) Internal marketing: cause for concern. Quarterly Review of Marketing 12(3/4), 21 24.

[16]. Nwankwo G.O. (1990) Prudential Regulation of Nigerian Banking. Lagos. University of Lagos Press.

[17]. Osaze B.E. (2000) The Nigerian Capital Market in the African and Global financial System. Benin City: Bofic Consulting group Ltd.

[18]. Papasolomou-Doukakis, I. (2002) Internal marketing: a means for creating a sales or marketing orientation?. Journal of marketing 8, 87-100.

[19]. Parasuraman, A., Zeithami, V.A \& Berry, L.L.(1985)," A conceptual model of service quality and its implication", journal of marketing,vol.49 pp.41-50.

[20]. Parasuraman, A., Zeithami, V.A \& Berry, L.L.(1994),’Reassessment of expectations as a comparison standard in measuring service quality: implication for future research", journal of marketing, vol. 58,pp111-124.

[21]. Pearls, Fritz S.,Ralph F.,Hefferline \& Paul Goodman (1951) Gestalt therapy: Excitement and growth in the human personality. New York: Dell.

[22]. Piercy, N.\& Morgan, N. (1991) Internal marketing-the missing half of the marketing programme. Journal of Long Range Planning 24, 82-93.

[23]. Piercy,N \& Morgan, N. (1991) Internal marketing : the missing half of the marketing program. Long Range Planning, 24: 82-93.

[24]. Piercy,N.F. (1995) Customer satisfaction and the internal market. J. Market. Practice Applied Market. Sci., 22-44. 
[25]. Powell, T.C. (1995), “Total quality Management as Competitive Advantage: A Review and Empirical Study", Strategic Management Journal, Vol. 16, pp. 15-37.

[26]. Rafiq, M. \& Ahmed, P.K. (2000) A meta-model of internal marketing. In R.J. Varey \& B.R. Lewis (eds), Internal Marketing: Direction for Management. Routledge,pp. 192-220.

[27]. Rafiq, M. \& Ahmed, P.K. (2000). ' Advances in the internal marketing concept: Definition, sythensis and extension ', Journal of Service Marketing, 14(6), 449-462.

[28]. Ravichandran, K. Prabhakaran, S. \& Kumar, S.A. (2010), “Application of Servqual Model on Measuring Service Quality: A Bayesian Approach”, Enterprise Risk Management, Vol. 1, No 1, pp. E9.

[29]. Reynoso, J. \& Moore, B. (1995), “ Towards the measurement of internal service quality”, International journal of service industry Management, Vol. 6, No.3,pp.64-83.

[30]. Ritzer, G. (2003) Rethinking globalization: Globalization/grobalization and something/nothing. Sociology: A journal of review.

[31]. Ruyter, K. \& Bloemer, J. (1995), “Integrating service quality and satisfaction: Paying in the Neck, or Marketing Opportunity?” Journal of consumer satisfaction, Dissatisfaction and complaining Behaviour, Vol.8, pp. 44-52.

[32]. Sasser, W,E. \& Arbeit, S.P. (1980), “Selling jobs in the service sector”, Business Horizons, Vol. 23 No 1 , pp 58-59.

[33]. Varey Richard J \& Lewis Barbara R. (2000). " Internal Marketing. Directions for Management" Routledge, Taylor \& Francis Group.

[34]. Walter R. Greene, Gary D. Walls; Larry J. Schrest (1994) Internal Marketing: The key to external marketing success, journal of service marketing vol 8 Iss 4, Pp 5-13.

[35]. Wiebeke, J., Ahearne, M., Lam, S. \& Van Dick, R. (2009) The role of leaders' job perceptions. International journal of Hospitality Management, 29(1), 62-71.

[36]. Zeithami, V., Parasuraman, A. \& Berry, L. (1990), “ Delivering Quality Service”. Free Press, New York, NY.

[37]. Zeithami, V.A, Berry, L.L. \& Parasuraman, A. (1988) Communication and control processes in the delivery of service quality. Journal of Marketing 52, 35-48. 